\title{
Os Transgênicos e os Riscos à Saúde
}

\section{Marilena Lazzarini e Andrea Lazzarini, IDEC/SP}

Antes de mais nada, gostaria de fazer uma breve apresentação do Idec - Instituto Brasileiro de Delesa do Consumidor, uma ONG fundada em 1987, que acompanha de perto a questão dos alimentos transgênicos desde 1996. O ldec chegou a integrar a CTNBioComissão Técnica Nacional de Biossegurança, no seu início, mas saiu por não concordar com os procedimentos e principalmente com a pressa da Comissão em liberar experimentos transgênicos.

Mas, a atuação mais efetiva da entidade se deu a partir de setembro de 1998, com o ajuizamento de una ação judicial que até hoje impede a liberação de transgênicos no país. A ação tem por objetivo a proteção do meio ambiente, a saúde da população e o direito à informação, sendo que minha breve apresentação enfocará especificamente os aspectos de saúde e informação (considerando que outros aspectos relevantes - meio ambiente, agricultura, economia - serão abordados com muito mais propriedade por outros expositores).

Enquanto representante de consumidores, a primeira indagação que o ldec entende que deva ser feita, sob a ótica do cidadão, a respeito das espécies transgênicas é: por que devemos correr riscos? Sabemos que qualquer novo produto, qualquer nova atividade que afete diretamente a sociedade deve ter seus possíveis riscos analisados, mas somente depois de considerados seus eventuais benefícios. No caso específico dos transgênicos, se não há benefícios concretos para a sociedade, por que temos que considerar os riscos? Há benefícios que justifiquem os riscos potenciais decorrentes de seu consumo? Se a resposta é negativa, não se admite a submissăo dos seres aos riscos. A título ilustrativo, vale comparar a análise que se precede à liberação de medicamentos (inclusive oriundos da biotecnologia, como a insulina), onde essa relação risco-benefício é televada.

O medicamento é utilizado, getalmente, em uma pessoa doente, sem muitas alternativas terapêuticas e, portanto, há algum nível de aceitação de risco, como de ocorrência de reaçóes alérgicas. Já o alimento é consumido por pessoas, no geral, saudáveis, que não aceitan riscos previsíveis ou imprevisíveis na ingestão de alimentos.

Ainda há que se ponderar que o medicamento chega ao consumidor de forna altamente purificada, enquanto o alimento é consumido por completo, incorporando não apenas a modificação genética, mas também quaisquer substâncias formadas nas alterações resultantes diretamente da manipulação genética, ou, indiretamente, devido a efeitos não esperados ou, ainda, devido a mudanças em práticas agrícolas (aumento do uso de agrotóxicos) ou condiçóes ambientais decorrentes das características do novo produto. 
Ademais, o organismo produtor do medicamento não é liberado no meio ambiente, mas a planta transgênicá é produzida no meio ambiente, decorrendo daí conseqüências ambientais não avaliadas adequadamente até o momento.

Um outro aspecto relevante é que, embora muitos riscos dos alimentos transgênicos possam ser descartados antes da libetação, mediante ensaios prévios rigorosos, boa parte dos riscos toxicológicos permanecem imprevisiveis. Como no caso do medicamento, muitas reaçöes adversas graves apenas são identificadas na fase pós-comercializaçăo, quando populaçōes maiores são expostas. E, justamente porque boa parte dos riscos não pode ser identificada, nem excluída antes da comercialização, mesmo fazendo uma rigorosa análise, deve-se, também, assegurar mecanismos adequados para permitir a pesquisa pós-mercado.

Salientamos, por fim, que o medicamento é acompanhado de extensa informação sobre as características do produto, seus riscos e benefícios (embora a especificação de origem transgênica ainda não seja respeitada em alguns casos), enquanto que as espécies transgênicas, até momento, nos maiores países produtores e consumidores - EUA e Argentina - não vêm acompanhado de orientação ou rotulagem completa.

Feitos esses apontamentos, temos que os transgênicos até agora liberados em escala comercial em alguns países, dos quais a soja eo milho se destacam em termos quantitativos, não trazem nenhum benefício real do ponto de vista dos consumidores: não são mais baratos, gostosos, nutritivos, e, tampouco, mais seguros que os similares (convencionais), implicando, portanto em riscos aos seres vivos absolutamente dispensáveis. Esse é um aspecto relevante a ser objeto de reflexão e em poucas ocasióes se tem discutido, acredito que pelo fato de a sociedade ter sido surpreendida, "arropelada" pelos produtos advindos dessa nova tecnologia, tendo restado somente à sociedade una análise a partir do risco e não risco $\mathrm{x}$ benefício.

O que pode acontecer para nossa saúde e para o meio ambiente? Quais os impactos sócio-econômicos em cada região, em cada país? Quais as implicações éticas?

Já partindo para a análise de riscos, é justamente a falta de avaliação prévia à liberação para o consumo que aterroriza o Idec. Esta é nossa maior preocupação: sequer sabemos "onde estamos pisando".

Há quem acredita que o fato de já ter sido liberado nos Estados Unidos basta, em razão do controle mais rigorosos dos órgãos competentes norte-americano. Mas, saben como aconteceu a liberação nos Estados Unidos? Sem qualquer avaliaçãa de riscos, já que o FDA - Food and Drugs Administration utilizou-se de um "conceito" inaplicável no caso para não avaliar: a equivalência substancial". Cientistas eminentes contestaram e ainda contestam as evidentes deficiências na avaliação de risco desses produtos, até agora baseada nesse questionável conceito, chamando-a de metodologia inadequada cientificamente ou "pseudo-científica", pois preconiza um número limitado de ensaios para a determinação da composiçẫo e do potencial toxicológico dos produtos.

: $O$ conceito da Equivalência Substancial fol recomendado no "Seminário da OCDE sobre a avaliaçăo da segurança dos alimentos", $12-15$ setembro de 1994, Oxford, Reino Unido e reiterado na Consuita FAOMHO sobre biotecnologia e segurança dos alimentos em 1996. 
Para se ter uma idéia, esse tipo de avaliação exclui a possibilidade de que substâncias tóxicas, năo "selecionadas" para os testes, estejam presentes nesses novos alimentos, aceita como suficientes os testes em uma ou poucas espécies de animais de laboratório, sempre por poucas semanas, e a falta de ensaios de toxicologia crônica. Também năo exige nenhum teste, eticamente aceitável, em grupos de seres humanos, como recomendam alguns especialistas.

A tese de que a soja RRé "substancialmente equivalente" à convencionalé um bom exemplo de como não procede este conceito, pois se identificou, entre outros aspectos, um aumento estatisticamente significante do teor de ácido graxo C 22:0 (Dihydroxycholesterol) (3) e um aumento de $26 \%$ no inibidor de tripsina na soja deslipidificada, sem uma explicação científica para isto, evidenciando o quanto a mesmaé falha.

Não é por outra razão que o FDA - Food and Drug Administration está sendo processado nos EUA, país que iniciou a adoçăo e aplicação da equivalência substancial na "desregulamentação" desses produtos, eque influenciou processos idênticos em vários países. $\mathrm{Na}$ ação judicial, o FDA foi obrigado a revelar cerca de quarenta e quatro mil páginas de documentos e memorandos internos, quando se pôde constatar que a Agência desconsiderou as preocupaçôes de seus próprios cientistas que alertavam para os riscos inerentes e desconhecidos dessas novas espécies. (Alguns dos principais documentos que comprovam a opinião técnica dos cientistas do órgão podem ser lidos acessando o site de uma das organizaçóes autoras da ação www.biontegrity.org)

En que pese esse desconhecimento quase completo sobre essas espécies, alguns riscos potenciais para a saúde já foram apontados por entidades científicas de todo o mundo:

$>\mathrm{O}$ aumento ou potencialização dos efeitos de substâncias tóxicas naturalmente presentes nas plantas manipuladas geneticamente pode ocotrer, como adverte o Dr. Michael Hansen, biólogo da Consumers Union, exemplificando o perigo do aumento das solaninas, cumarinas e outros alcalóides presentes em vários alimentos em quantidades abaixo das doses de risco aos consumidores. Por outro lado, outras substâncias podem ter a sua quantidade diminuída, como foi demonstrado com os fitoestrógenos genistina e daidzina presentes na soja e que protegem as mulhetes contra o câncer de seio, que diminuíram a sua quantidade em 12 e $14 \%$ em algumas variedades transgênicas resistentes ao glifosato.

$>$ O aumento das alergias alimentares, afecção subestimada pelas autoridades sanitárias e pelas empresas e que acomete parcela significativa da população, pode ocorrer devido à ingestäo de novas proteínas ou novos compostos que se formam nos alimentos geneticamente modificados. Essa possibilidade não é tăo remota assim, como foi demonstrado no caso da soja da Pioneer Hi-breed, que recebeu um gene da castanha-do-pará, causando alergia en pessoas que também eram sensíveis à castanha. Em março de 1999, pesquisadores do Instituto de Nutrição de York, Reino Unido, revelaram um aumento de $50 \%$ nos casos de alergia à soja em 1998, afirmando que esses resultados poderiam ser devidos a introdução da soja geneticamente modificada na alimentação.

$>$ Essa possibilidade de que aumentem as alergias alimentares pela introdução dos transgênicos reforça, também, a necessidade da rotulagem plena desses alimentos (sobre a qual cratarei mais adiante). $O$ dados norte-americanos disponíveis estimam a incidencia dessa 
doença em 1,5\% da população adulta e $5 \%$ das crianças menores de 3 anos. Para Maden: "a multidão de substâncias que poden causar reações alimentares adversas e a falta de bons testes tomam difícil a tarefa do diagnóstico correto. As autoridades deveriam estar conscientes dos riscos do alimento näo tradicional e do uso novo de alimentos convencionais. Deveria ser obrigatória a rotulagem para mostrar a natureza dos ingredientes, especialmente os alergênicos".

$>$ Outra preocupação refere-se à possibilidade do aumento da resistência bacteriana a antibióticos, pelo uso de genes marcadores que conferem esta característica na "construçấo" dos alimentos geneticamente modificados e que podem ser transferidos a bactérias que infectam o ser humano e os animais. $O$ aparecimento de super-bactérias resistentes a todos os antibióticos é hoje a maior preocupação das autoridades mundiais de saúde. Em maio de 1999, a Associação Médica Britânica, divulgou um manifesto a esse respeito, pedindo, inclusive, a moratória nas autorizaçóes de alimentos transgênicos, apontando o uso desses genes marcadores como uma séria ameaça à saúde pública, apelando para a proibição imediata do seu uso.

$>$ Também é relevante a possibilidade de aumento de resíduos de determinados agrotóxicos nos alimentos e nas águas de abastecimento, devido ao uso em quantidade muito maior dessas substâncias em plantas resistentes. Um bom exemplo ocorreu no Brasil, em que se năo tivesse ocorrido o pedido e o parecer favorável da CTNBio para a liberação da soja $R R$, resistente a glifosa to, o Ministério da Saúde não tentaria aumentar 100 vezes o limite de resíduos desse veneno nos produtos à base de soja (Portaria 764, de 24 de setembro de 1998), ou seja, de 0,2 partes por milhão para 20 partes por milhão, constituindo-se em uma conseqüência danosa para os consumidores. ${ }^{2}$

$>$ Além dos aspectos sanitátios, propriamente ditos, o impacto dos transgênicos do ponto de vista ambiental, que também vem sendo absurdamente desconsiderados, pode trazer de forma indireta riscos a saúde e a segurança alimentar. A perda da diversidade genética na agricultura, aliada a concentração do mercado de sementes por poucas empresas multinacionais, em escala global, poderá fazer com que umas poucas variedades transgênicas venham a substituir tanto as variedades melhoradas por processos convencionais como as milhares de variedades selecionadas pelos próprios agricultores, chamadas locais ou tradicionais, que são a base da subsistência de metade dos agricultores do mundo.

\section{Casos concretos}

$>$ Um episódio dramático, que demonstra o perigo de uma análise de rísco superficial e sem a exigência de rotulagem, com o aparecimento de riscos imprevistos, envolveu um suplemento alinentar à base de triptofano (um aminoácido essencial), obtido por engenharia genética, da empresa japonesa Showa Denko, que causou 37 mortes e milhares de casos de invalidez nos Estados Unidos, por causa da Síndrome da Eosinofilia Miálgica.

\footnotetext{
${ }^{2}$ Após a contestação ao referido aumento, pelo IDEC e outras entidades, outra portaria foi publicada, estipulando em $2 \mathrm{ppm}$ o limite de glifosato na soja, ainda assim, dez vezes mais
} 
$>$ A pesquisa do professor Arpad Pusztai, publicada em 1999, que, no Roswell Institute, de Aberdeen, Escócia, apontou alteraçóes no sistema imunológico e em órgãos vitais de ratos alimentados com batata transgênica, também reforça a suspeita do potencial de danos não previstos advindos dos transgênicos. A polêmica provocada por esse estudo após a divulgação levou Pusztai a receber o apoio de cientistas de 16 países da Europa ${ }^{3}$.

$>$ Em 2000, a Monsanto informou ao governo britânico que detectou outros dois fragmentos de genes imprevistos na soja Roundup Ready, o que exigiria uma reavaliação das autorizações feitas em diversos países. O próprio Pusztai, numa entrevista em 1999, levantou questionamentos fundamentais sobre a metodologia dos estudos publicados pela Monsanto, que pretendia mostrar a ausência de efeitos observáveis em animais após a ingestão de soja RR. Ele assinalou três problemas: o uso de animais adultos em vez de jovens; a baixa proporção de soja no conteúdo proteico da ração usada e; a falta de qualquer medição precisa dos órgãos afetados pela presença de material transgênico na dieta.

$>$ Neste mês (julho de 2002), uma pesquisa encomendada pela Agência Britânica de Padróes Alimentares indicou que DNA de alimentos transgênicos pode ser encontrado em bactérias que vivem no estômago humano. Segundo notícia da Reuters, cientistas da Universidade de Newscastle (Grä-Bretanha) realizaram experiência com 7 voluntários que tiveram parte de seu intestino extirpado. Foi dado a eles uma única porção de hamburger com milkshake contendo genes de soja transgênica. Amostras da bactéria intestinal foram coletadas. Em três dos sete voluntários foi encontrado o gene resistente a herbicida da soja trasngênica em pequenos níveis (demonstrando que um porção relativamente grande do DNA da soja sobreviveu à passagem pelo intestino).

Portanto, a conclusão a que se chega é que não foram realizados estudos experimentais suficientes sobre os potenciais efeitos adversos dos alimentos transgenicos para justificar a segurança desses produtos. Essa conclusão consta de una revisão bibliográfica publicada na revista de Saúde Pública de Madriri , sobre pesquisas a respeito dos potenciais efeitos adversos à saúde, provocados pela ingestão dos alimentos modificados geneticanente. A revisão foi feita junto às 2 maiores bases de dados, a

${ }^{3}$ La publicación de ese articuło fué seguida de una polémica oleada de comentarios críticos al mismo1418. En respuesta a esas críticas, los autores del estudio destacaron entre otros interesantes aspectos, la escasisima atención que se ha venido prestando al potencial consumo de los AMG por parte, entre otros grupos, de aquellas personas con digestiones anormales resultantes de trastornos gastrointestinales crónicos19. Precisamente, entre los graves problemas que al respecto podrían potencialmente plantearse, queremos destacar los resultados de un interesante estudio experimental en ratones, en el que se demostró que la ingestión de DNA ajeno puede alcanzar los leucocitos periféricos, el bazo y el hígado a través de la mucosa de la pared intestinal20. Ello supone que un gen transferido podria ser incorporado en un lugar impredecible del genoma, con todas las consecuencias que de ello podrian derivarse.

${ }^{4}$ Ver. Esp. De Salud Publica vol.74 no.3 Madrid May/June 2000. A pesquisa fol realizada pelos pesquisadores José L. Domingo Roig e Mercedes Gómez Arnäiz, do Laboratório de Toxicologia Y Salud Medioambiental, Facultad de Medicina, Universidade "Rovira e Virgili", Tarragona 
MEDLINE a TOXLINE, e outras referências bibliográficas na INTERNET. Os autores encontraram apenas 6 estudos experimentais originais publicados e chaman a atenção para a ausencia de referencias correspondentes a estudos ou avaliaçöes nutricionais, toxicológicas e imunológicas relacionadas a esses alimentos, com caráter experimental. As conclusoes dos autores:

“... podem-se estabelecer algumas conclusões referentes ao conhecimento do estado atual dos potenciais efeitos adversos sobre a saúde dos alimentos geneticamente modificados. Assim, embora as manifestações nos meios de comunicação, levadas a cabo por representantes das empresas de biotecnologia que se dedicam à elaboração dos alimentos geneticamente modificados, indicarem que, de acordo com seus estudos o consumo de alimentos geneticamente modificados já comercializados ou em vias de serem comercializados, não implica em riscos para a saúde humana, diante da ausência de publicaçöes de experimentos originais, o manifestado por ditas empresas se converte em mero a to de fé, pelo fato de os resultados não haver podido ser devidamente julgados ou comprovados pela comunidade científica internacional."

"Tal como temos indicado, até a presente data, nas bases de dados MEDLINE e TOXLINE, se compila apenas uma cifra muito reduzida de artigos correspondentes a estudos experimentais diretamente relacionados com o tema objeto desta revisão. Nenhum deles pertence a companhias do setor biotecnológico ou foi desenvolvido em agencias ou urganismos reguladores....". A tabela anexo em oferece um panorama sobre os estudos compilados.

Portanto, de um lado tem-se que a avaliação riscos $\mathrm{x}$ benefício que demonstra que não há benefício algum para a sociedade para justificar os riscos impostos por essa nova tecnologia aplicada à produçáo de alimentos. De outro lado, existem riscos sérios apontados por entidades científicas respeitadas de todo o mundo que reforçam a necessidade de rejeição por parte da sociedade dessa tecnologia aplicada à agricultura. Mas, isso não é tudo. Nos países em que já houve liberação de algumas espécles transgênicas para comercialização e consumo (EUA e Argentina, principalmente), vê-se que as autoridades competentes não estão executando um acompanhamento pós-mercado, isto é, um rastreamento que propiciaria, ainda que a posteriore, uma investigação científica para avaliar os impactos na saúde da população.

(Rotulagem)

Aí sustenta-se a imprescindibilidade da rotulagem de transgênicos. $O$ direito à informação e à liberdade de escolha, ambos assegurados pelo Código de Defesa do Consumidor (artigos 6". Il e III e 31), para o Idec, já são suficientes para justificar a necessidade da rotulagem. Ademais, apenas a informação precisa e completa (gene doador, percentual de ingrediente transgênico, etc) pode permitir uma investigaçăo e análise sobre o impacto dos transgênicos na alimentação, bem como rastrear a origem, em caso de danos. 
Vê-se que a rotulagem de transgênicos é um aspecto da maior relevância. Sem isso, continuará uma incógnita o impacto de cada espécie na saúde da população. Como é notório, nos EUA, não é obrigatória a informação no alimento (seja no produto "in natura", seja no industrializado) de que se trata de alimento contendo ingrediente transgênico e, muito menos, sobre qual o(s) gene(s) inserido(s). Portanto, não há nenhum meio de se pesquisar e de se acompanhar os eventuais problemas decorrentes, como aumento de alergias, aumento de resistência a antibióticos, algumas reaçôes inadvertidas, inesperadas em razão da falta de vontade de encontrar tais problemas.

Nos EUA e na Argentina, principais produtores em termos quantitativos de espécies ttansgênicas, não há regras para rotulagem de transgênicos - o que traz um impacto negativo para todo o mundo. Outros países, como Japão, Austrália, etc têm regras, porém pouco efetivas, como é o caso também do Brasil.

Felizmente, a União Européia que já mantinha um limite obrigatório de informação de $1 \%$ de ingrediente transgênico, acaba de avançar com vistas a garantir maior respeito ao direito dos consumidores de saberem o que comem. $O$ Parlamento Europeu aprovou no início de julho de 2002 uma norma que exige a rotulagem de todos os alimentos transgênicos, reduzindo-se o limite atual de $1 \%$ para $0,5 \%$. A proposta aprovada no Parlamento Europeu ainda necessita ser aprovada pela Comissão Européia para se transformar em lei.

\section{Situação no Brasil em 2002}

Como decorrência da decisão judicial dada na ação proposta pelo Idec e que até hoje vigora, a liberação de espécies transgênicas em escala comercial está condicionada à realização de prévio estudo de impacto ambiental; elaboração de norma para avaliação de impactos na saúde e à elaboração norma de rotulagem.

$\mathrm{Na}$ questão ambiental recentenente houve um avanço. O CONAMA - Conselho Nacional do Meio Ambiente aprovou, em 12/06/02, uma resolução (Resolução 305) sobre licenciamento ambiental de organismos geneticamente modificados. A referida resolução não contempla todas as reivindicaçôes da sociedade que participou ativamente do processo de discussão ao longo de quase 2 anos lo Idec, o Greenpeace, a ASPTA entidades que compõem a Campanha "Por um Brasil livre de Transgenicos"] e que, em síntese, gostaria de ver exigido estudo prévio de impacto ambiental para o uso da tecnologia. (Assim, para a Monsanto poder utilizar sua soja RR para qualquer fim, necessitaria realizar EIA; e assim por diante). O texto aprovado não é tão rigoroso, mas dá ao órgão licenciador (IBAMA érgãos estaduais) instrumentos para obrigar a empresa detentora da tecnologia a se submeter a procedimentos rígidos. Caberá à sociedade agora acompanhar de perto a atuação dos órgãos ambientais.

Com relação à rotulagem, em 18 de julho de 2001, o Presidente da República baixou o Decteto 3.871. Na opinião do Idec, o referido decreto desrespeita o consumidor, pois restringe a rotulagem aos embalados (ou seja, os alimentos in natura não serão 
rotulados), e em que seja detectada a presença de transgênico (ou seja, exclui os produtos altanente processados - que representam uma enorme quantidade de alimentos) e ainda somente acima do percentual de $4 \%$ (quatro por cento) por ingrediente transgênico.

O Idec e o Ministétio Público Federal ajuizaram uma ação civil pública questionando a validade do Decreto 3.871/01. Não foi deferida a liminar, mas a decisão final ainda está pendente de julgamento.

No dia 18 de julho passado, oldec enviou uma carta ao Presidente da República pedindo a revogação do Decreto. A resposta acabou de chegar via telegtama e informa que a carta foi encaminhada aos Ministérios da Agricultura e da Saúde!!!

Por fim, no aspecto de saúde nada avançou. É lamentável a condução dada pelo então Ministro da Saúde, José Serra, e pela ANVISA - Agência Nacional de Vigilância Sanitária, à questăo. Apesar das reiteradas cartas e documentos encaminhados pelo Idec, pela Campanha "Por um Brasil livre de transgênicos" e pelo Fórum Nacional das Entidades Civis de Defesa do Consumidor, e das audiências realizadas, nada aconteceu. 